\title{
Genetically Modified Medicago truncatula Lacking Calcium Oxalate has Increased Calcium Bioavailability and Partially Rescues Vitamin D Receptor Knockout Mice Phenotypes
}

\author{
Xiangkai Li ${ }^{*}$, Jian Yang ${ }^{2}$, Jay Morris ${ }^{3}$, Ashley Hester ${ }^{2}$, Paul A. Nakata ${ }^{2}$ and Kendal D. Hirschi ${ }^{2,4}$
}

${ }^{1}$ Key Laboratory of Cell Activities and Stress Adaptations, School of Life Sciences, Lanzhou University, Lanzhou, Gansu, 730000, P. R. China

${ }^{2}$ United States Department of Agriculture/Agriculture Research Service, Children's Nutrition Research Center, Department of Pediatrics, Baylor College of Medicine,

Houston, Texas 77030 , USA

${ }^{3}$ Department of Molecular Medicine, University of Texas Health Science Center at San Antonio, San Antonio, TX 78229, USA

${ }^{4}$ Vegetable and Fruit Improvement Center, Texas A\&M University, College Station, Texas 77845, USA

\begin{abstract}
Background: How the distribution and sequestered form of plant macro/micro-nutrients influence their bioavailability, and ultimately impact human health, are poorly understood. The legume Medicago truncatula has a portion of its tissue calcium $(\mathrm{Ca})$ sequestered in the form of the $\mathrm{Ca}$ oxalate $(\mathrm{CaOx})$ crystal which reduces its nutritional value in terms of Ca bioavailability. The calcium oxalate deficient 5 (cod5) mutant has a total Ca content similar to wild-type (WT) plants, but sequesters less of its tissue $\mathrm{Ca}$ in the form of the CaOx crystal. Previous shortterm mice feeding studies suggest that this difference is responsible for the improved Ca bioavailability of the cod5 plants compared to WT plants.
\end{abstract}

Objectives: To perform long term feeding studies with Vitamin D Receptor Knockout (VDR-KO) mice and the nutritionally improved cod5 line to assess the impact of increased Ca bioavailability on VDR-KO Ca deficiency phenotypes.

Methods: To assess the ability of diets containing cod5 plant material as the sole Ca source to rescue the Ca deficiency phenotypes of the VDR-KO mice we conducted both short term and long term experiments. Specifically, Ca absorption and utilization were measured short term (24-hour) in the hind limb bones and duodenum tissue of VDR-KO mice that were fed either an intrinsically ${ }^{45} \mathrm{Ca}$ labeled cod5 or WT Medicago diet. Long term (20-day) bodyweight gain and change in Bone Mineral Density (BMD) were also measured over a 20 day period in VDR-KO mice fed either a cod5 or WT Medicago diet.

Results: In the 24-hour feeding study, ${ }^{45} \mathrm{Ca}$ incorporation was found to be $46.3 \%$ (male) or $53.9 \%$ (female) higher in hind limb bones $(P<0.01$ ); and $32.5 \%$ (male) or $38.5 \%$ (female) higher in duodenums $(P<0.01$ ) in VDR-KO mice fed cod5 than those fed WT plants. In the 20-day feeding study, the VDR-KO mice (male) fed cod5 gained $38.1 \%$ more bodyweight than those fed WT plants $(P=0.06)$. The increase of BMD after 20 days in the VDR-KO mice (male) fed cod5 diets was $22.5 \%$ higher than those fed WT diets $(P=0.17)$.

Conclusions: Our study confirms and extends an earlier study by showing that cod5 Medicago not only had higher $\mathrm{Ca}$ bioavailability but it can also rescue, in part, the VDR-KO Ca deficiency phenotypes. Thus, the removal of $\mathrm{CaOx}$ from a plant-based diet appears to be a viable long-term dietary option to boost bioavailable Ca levels and help combat $\mathrm{Ca}$ related disorders.

Keywords: Calcium bioavailability; Medicago trunculata; Vitamin D receptor knockout mice; Oxalate; Calcium Oxalate Deficient 5 (cod5)

Abbreviations: Ca: Calcium; CaOx: Calcium Oxalate; WT: Wildtype; BMD: Body Mineral Density

\section{Introduction}

Nutritional recommendations agree on the importance of a predominantly plant-based diet (http://www.choosemyplate.gov); however, sole reliance on plants for nutrition can limit the intake of the essential nutrients calcium (Ca), vitamins B12 and D [1]. Bioavailable $\mathrm{Ca}$ is critical to human health, which is needed specifically for bone growth and muscle control. Inadequate Ca uptake can cause imbalanced $\mathrm{Ca}$ levels in serum, resulting in hormone-regulated adaptation which promotes the mobilization of $\mathrm{Ca}$ from bone $\mathrm{Ca}$ phosphate and increases the risk of osteoporosis [2,3]. In recent years, concerns over the development of osteoporosis in an aging population has led to an increase in food fortification of $\mathrm{Ca}$ in the United States $[4,5]$. Several studies show that $\mathrm{Ca}$-fortified vegetables can increase $\mathrm{Ca}$ uptake in mice and humans [6,7], but the long term efficacy of these fortification activities remains questionable [8].
Calcium in plants exist as complexes with oxalate, phytate, and fiber $[9,10]$, all of which suppress Ca bioavailability. It is believed that the $\mathrm{Ca}$ oxalate $(\mathrm{CaOx})$ content is the best predictor of $\mathrm{Ca}$ availability [11]. For example, spinach contains a high concentration of Ca but a significant amount of this $\mathrm{Ca}$ is complexed with oxalate which reduces its Ca bioavailability to about $5.0 \%$ [12]. However, in soybeans oxalate levels are similar to spinach but its Ca bioavailability is around $20 \%$

*Corresponding author: Xiangkai Li, School of Life Sciences, Lanzhou University, Tianshui Nan Lu \#222, Lanzhou, Gansu, 730000, P. R. China, Tel: 86-9318912561; Fax: 86-931-8912560; E-mail: xkli@Izu.edu.cn

Received December 06, 2012; Accepted December 21, 2012; Published December 27, 2012

Citation: Li X, Yang J, Morris J, Hester A, Nakata PA, et al. (2013) Genetically Modified Medicago truncatula Lacking Calcium Oxalate has Increased Calcium Bioavailability and Partially Rescues Vitamin D Receptor Knockout Mice Phenotypes. J Bioequiv Availab 5: 047-052. doi:10.4172/jbb.1000133

Copyright: (C) $2013 \mathrm{Li} \mathrm{X}$, et al. This is an open-access article distributed under the terms of the Creative Commons Attribution License, which permits unrestricted use, distribution, and reproduction in any medium, provided the original author and source are credited. 
Citation: Li X, Yang J, Morris J, Hester A, Nakata PA, et al. (2013) Genetically Modified Medicago truncatula Lacking Calcium Oxalate has Increased Calcium Bioavailability and Partially Rescues Vitamin D Receptor Knockout Mice Phenotypes. J Bioequiv Availab 5: 047-052. doi:10.4172/ jbb.1000133

[13]. This variation among plants warrants further investigation of how $\mathrm{CaOx}$ impacts bioavailability.

In humans, oxalate cannot be metabolized so after ingestion and absorption it is usually excreted. In some instances; however, the oxalate can complex with Ca before excretion occurs and result in the formation of kidney stones, particularly in those with low $\mathrm{Ca}$ intake [14,15]. Patients suffering from hyperoxaluria, a condition characterized by over-production of oxalate in the body leading to the development of kidney stones, are advised to avoid high-oxalate foods and to supplement with $\mathrm{Ca}[16]$. Given the importance of adequate $\mathrm{Ca}$ for human health, and the potential negative health effects of excessive oxalate consumption for those with oxalate sensitivities, manipulation of $\mathrm{CaOx}$ formation is an important target of biofortification efforts, which aims to enhance the bioavailability of $\mathrm{Ca}$ and reduce oxalate content in food crops [17].

The low oxalate mutant from the model forage legume Medicago trunculata, calcium oxalate deficient 5 (cod5), has been previously identified [18]. The cod5 plant is devoid of prismatic crystals of $\mathrm{CaOx}$. Growth studies and total mineral composition measurements indicate no substantial difference between cod5 and WT with the exception of oxalate crystal content [19]. The removal of crystalline oxalate in $M$. truculata results in increased $\mathrm{Ca}$ absorption in mice [6]. However, no long-term feeding studies have been carried out to evaluate the benefits of cod5 diets due to the lack of easy-to-monitor physiological phenotypes in normal mice fed with low Ca diets.

The Vitamin D Receptor (VDR) is a member of the superfamily of nuclear receptors which regulates gene expression in a ligand activated manner [20]. The hormonal metabolite of vitamin D, 1, 25-dihydroxyvitamin $\mathrm{D}_{3}\left(1,25(\mathrm{OH})_{2} \mathrm{D}_{3}\right)$ functions as the ligand for VDR [21-23]. VDR dependent transcellular Ca absorption is important in maintaining $\mathrm{Ca}$ homeostasis when $\mathrm{Ca}$ concentrations are low [22]. The VDR knockout (VDR-KO) mice exhibit decreased serum Ca levels, reduced duodenal $\mathrm{Ca}$ absorption, impaired bone formation and growth retardation on $0.5 \% \mathrm{Ca}$ diet $[22,24,25]$. However, on an excessive $2 \% \mathrm{Ca}$ diet, the serum Ca balance, duodenal Ca intake, bone growth and body weight gain in VDR-KO mice can be partially restored, likely through a VDR independent system [24-26]. Therefore the enhanced sensitivity to dietary Ca levels of VDR-KO mice makes them ideal models to test the bioequivalence and bioavailability of $\mathrm{Ca}$ in $\operatorname{cod} 5$ lines during long term feeding regimes.

In our study, we used VDR-KO mice to test the bioavailability of Ca in cod5 and WT Medicago leaf tissue to evaluate the long-term impacts of a cod5 based diet. Our results demonstrate the longitudinal impacts of reduced $\mathrm{CaOx}$ content in plant diets in animals with defects in Ca metabolism.

\section{Materials and Methods}

\section{Plant growth and preparations}

Medicago truncatula WT (cv. Jemalong, ecotype A17) and cod5 seeds were nicked with a razor blade and allowed to germinate on agar plates. The germinated plants were then grown hydroponically for 30 days before the leaves were cut back [27]. To intrinsically label WT and cod5 Medicago with ${ }^{45} \mathrm{Ca}$, the hydroponic solution was supplemented with $1 \mu \mathrm{Ci}{ }^{45} \mathrm{Ca} / \mathrm{L}$ after the removal of the leaves and grown for 30 additional days. Then the leaves were harvested and processed as described previously [6]. In brief, leaves were harvested and freeze dried $[18,28]$, and then the material was frozen in liquid nitrogen and ground to a powder with a mortar and pestle [6].

\section{Determination of bulk Ca and oxalate concentration}

Calcium concentration measurements were carried out using inductively coupled plasma atomic emission absorption spectrometry on weighed leaf samples (Soil, Water and Forage Testing Laboratory, Texas A\&M University). Each measurement was done in duplicate on three independently grown sets of plants. The results were averaged with standard error calculated [28].

Oxalate measurements were conducted as previously described [18]. In brief, weighed freeze-dried leaf samples were ground in water and centrifuged. The supernatant was decanted and the soluble oxalate measured using an oxalate diagnostic kit (Trinity Biotech 591-D). The amount of total oxalate was determined by simply omitting the centrifugation step and solubilizing the $\mathrm{Ca}$ oxalate crystals through the addition of $\mathrm{H}^{+}$-Dowex in dilute acid. The mixture was heated at $60^{\circ} \mathrm{C}$ for 1 hour, and the $\mathrm{pH}$ of the mixture was adjusted to between 5 and 7. The mixture then was charcoal filtered and centrifuged. The supernatant was then analyzed for oxalate content using the oxalate diagnostic kit (Trinity Biotech). Measurements were done in triplicate on three independently grown sets of plants.

\section{Diet preparation and mice genotyping}

Calcium limited AIN-93G diets were (Ca concentration 0.5\%) obtained from Research Diets (New Brunswick, NJ). To obtain various diets with low (0.5\%) or high $\mathrm{Ca}(2 \%)$ levels, Ca limited AIN-93G diets were mixed with freeze-dried WT, or cod5 plants, or other Ca chemicals $\left(\mathrm{CaCl}_{2}\right.$, or $\mathrm{CaC}_{2} \mathrm{O}_{4}(\mathrm{CaOx})$ ) (Table 1$) .3 .5 \mathrm{~g}$ of these diets were calorically and nutritionally equivalent (except for $\mathrm{Ca}$ ) to the standard AIN-93G diet [26]. Animal protocols were approved by the Baylor College of Medicine Institutional Animal Care and Use Committee [29]. VDR$\mathrm{KO}$ mice were generated by breeding heterozygous mice. At the age of ten days, tail clips were taken for genotyping. Genotyping Primers used were: Forward 5'-TTTGGATCCATGGAGGCAATGCAGCCAGC -3',

Reverse 5'-TTTGGTACCTCAGGAGATCTCATTGCCAAA CACCTC-3,

\section{Insert 5’-TTTGGATCCATGAAGCGCAAGGCCCTGTTC -3’ [21]}

On day 21 postpartum, confirmed VDR-KO mice or WT mice were weaned and assigned to the experiments based on their genotype and gender. Throughout the experiments, mice were housed in cages with ad libitum access to water and food prior to the initiation of the experiment. Before the feeding experiments, mice were maintained on AIN-93G diet that contains $2 \% \mathrm{Ca}[6]$.

\begin{tabular}{|c|c|c|c|c|c|}
\hline Diet name & $\begin{array}{c}\mathrm{Ca} \\
\text { Source }\end{array}$ & $\begin{array}{l}\text { Weight of } \\
\text { Ca Source } \\
\text { (g) }\end{array}$ & $\begin{array}{l}\text { Modified } \\
\text { Low } \mathrm{Ca}^{2+} \\
\text { AIN diets } \\
\text { (g) }\end{array}$ & $\begin{array}{c}\text { Ca Content } \\
(\%)\end{array}$ & Kcal / kg \\
\hline Low Ca & N/A & 0 & 1000 & $0.5 \%$ & 3670 \\
\hline $2 \% \mathrm{Ca}$ & $\mathrm{CaCl}_{2}$ & 9.7 & 990.3 & $2 \%$ & 3633 \\
\hline $\mathrm{CaOx}$ & $\mathrm{CaC}_{2} \mathrm{O}_{4}$ & 11.2 & 988.8 & $2 \%$ & 3630 \\
\hline WT & $\begin{array}{c}\text { WT } \\
\text { Medicago }\end{array}$ & 233 & 767 & $2 \%$ & 3515 \\
\hline $\operatorname{cod} 5$ & $\begin{array}{c}\text { cod5 } \\
\text { Medicago }\end{array}$ & 233 & 767 & $2 \%$ & 3515 \\
\hline
\end{tabular}

Table 1: The ingredients, calcium and calorie composition in five diets used in the 20-day feeding study (per total weight of $1000 \mathrm{~g}$ ). 
Citation: Li X, Yang J, Morris J, Hester A, Nakata PA, et al. (2013) Genetically Modified Medicago truncatula Lacking Calcium Oxalate has Increased Calcium Bioavailability and Partially Rescues Vitamin D Receptor Knockout Mice Phenotypes. J Bioequiv Availab 5: 047-052. doi:10.4172/ jbb.1000133

\section{Measurement of $\mathrm{Ca}$ absorption in hind limbs and duodenum}

The VDR-KO mice were stratified and deprived of food for 24 hours and separated into two treatment groups ( $\mathrm{n}=12$ per group, six males and six females) using a randomized block design. After the 24 hours fasting, $3.5 \mathrm{~g}$ of each diet (Table 1) was placed in a glass food jar and placed into the cage. The amount of diet fed to each mouse represented $14.0 \mathrm{kcal}$. The small serving size of diets also insured that the mice ate the majority of the test meal over the allotted 24 hours. All mice were euthanized in $\mathrm{CO}_{2}$ chamber after 24 hours of feeding and placed at $4^{\circ} \mathrm{C}$ for 24 hours. The bones of the two hind limbs (femur, tibia, and fibula) were removed to measure bone $\mathrm{Ca}$ absorption. The soft tissue was surgically removed with a scalpel and the bones were then ashed to remove all the organic matter. The ashing was performed in a muffle furnace (Thermolyne Furnace, Barnsted International, Dubuque, IW) at $700^{\circ} \mathrm{C}$ for 30 hours. The duodenum was removed with a scalpel to measure duodenal $\mathrm{Ca}$ absorption. The tissue was collected in $1 \mathrm{ml}$ PBS buffer and sonicated to homogenization. The amount of ${ }^{45} \mathrm{Ca}$ incorporated in the sample was determined by a scintillation counter.

Long term feeding study and measurement of bone mineral density (BMD)

In the pilot study, male VDR-KO mice demonstrated higher sensitivity to $\mathrm{Ca}$ intake (data not shown), so we chose male VDR$\mathrm{KO}$ mice for long term feeding study. Ten or twenty (depending on the diet groups) male weaning VDR-KO mice were allotted into one of five different diets (Table 1) using a randomized block design [7]. $3.5 \mathrm{~g}$ of each diet was placed in a glass food dish and placed into the cage every day for 20 days. Water was allowed ad libitum throughout the experiment. Individual bodyweight was recorded every 24 hours. The BMD of the VDR-KO mice were measured by Dual Energy X-ray Absorptiometry (DEXA; PIXImus instrument, Lunar Corp., Madison, WI) on Day 1 and Day 20 for ten mice in each diet group. The precision was $\pm 1 \%$ coefficient of variation in vitro. DEXA test was taken on each mouse at the start and the end of the experiment to determine the bone mineral contents. The tests were carried out as previously described $[30,31]$.

\section{Data analysis}

The statistical analysis was performed using SPSS Version 11. T-test among five groups was conducted and subsequent pairwise comparisons were performed with Sidak multiple comparison test.

\section{Results}

Previously, we showed that cod5 diets display increased Ca bioavailability [6]. However, we have not demonstrated if this dietary change can impact animal growth and development. Here, we first tested ${ }^{45} \mathrm{Ca}$ incorporation into VDR-KO mice hind limbs and the duodenum. In a 24-hour feeding study, the VDR-KO mice fed ${ }^{45} \mathrm{Ca}$ labeled cod5 diets had $7.80 \pm 0.51 \%$ (Male) $/ 7.48 \pm 0.91 \%$ (Female) hind limb bone Ca incorporation while VDR-KO mice fed ${ }^{45} \mathrm{Ca}$ labeled WT Medicago diets had $5.33 \pm 0.46 \%$ (Male) $/ 4.86 \pm 0.77 \%$ (Female) hind limb bone $\mathrm{Ca}$ incorporation (Figure 1A). For duodenal Ca absorption, the VDR-KO mice fed ${ }^{45} \mathrm{Ca}$ labeled cod5 Medicago had $0.57 \pm 0.09 \%$ (Male) $/ 0.54 \pm 0.12 \%$ (Female) duodenal Ca incorporation while VDR$\mathrm{KO}$ mice fed ${ }^{45} \mathrm{Ca}$ labeled WT diets had $0.43 \pm 0.07 \%$ (Male) $/ 0.39 \pm$ $0.05 \%$ (Female) duodenal Ca incorporation (Figure 1B). The group fed the cod5 diet displayed $46.3 \%$ (male) $/ 53.9 \%$ (female) higher $\mathrm{Ca}$ absorption in hind limb bones $(P<0.01)$ and $32.5 \%($ male $) / 38.5 \%$ (female) higher $\mathrm{Ca}$ absorption in duodenums $(P<0.01)$ than the group fed the WT diet.

Hind limb bone and duodenal Ca incorporation are important parameters reflecting body Ca uptake levels [25]. Therefore, these results demonstrated that the cod5 diet has higher Ca bioavailability in VDR$\mathrm{KO}$ mice. However, the long-term physiological impact of $\mathrm{Ca}$ in cod5 diets was unknown. Previous studies show that VDR-KO mice have bone and growth defects that are associated with low $\mathrm{Ca}$ absorption. These pathological phenotypes in VDR-KO mice can be partially rescued by high Ca intake [25]. Here we tested whether the removal of oxalate crystals in cod5 could be a sufficient dietary alteration to rescue VDR-KO mice phenotypes. Male VDR-KO mice were divided into five dietary groups $(\mathrm{n}=10$ for $0.5 \% \mathrm{Ca}, 2 \% \mathrm{Ca}$ and $\mathrm{CaOx}$ groups; $\mathrm{n}=20$ for WT and cod5 groups), and the diets were prepared as shown in table 1. A low $\mathrm{Ca}$ diet $(0.5 \% \mathrm{Ca})$ was used as a negative control. A diet that contains $2 \% \mathrm{CaCl}_{2}$ was used as positive control. The $\mathrm{CaOx}$ diet which contains $2 \%$ total Ca but only $0.5 \%$ unbound $\mathrm{Ca}$ was used as a control to demonstrate that oxalate crystals act as antinutrients for $\mathrm{Ca}$. Both WT and cod5 diets contain $2 \%$ total Ca. After 20 days on each diet, the mice fed the $0.5 \%$ Ca diet gained an average of $1.75 \pm 0.47 \mathrm{~g}$ of weight while those fed the $2 \%$ Ca diet gained an average of $3.91 \pm 0.60 \mathrm{~g}$ of weight, showing the effect of increased $\mathrm{Ca}$ to rescue growth in these mutant mice. The $\mathrm{CaOx}$ diet group gained only $2.14 \pm 0.36 \mathrm{~g}$ of weight supporting the antinutrient effect of oxalate crystals. The VDR-KO mice fed cod5 diets for 20 days gained $3.37 \pm 0.45 \mathrm{~g}$ body weight, while the mice in the group fed WT diets gained $2.44 \pm 0.54 \mathrm{~g}$ of weight. In comparison, the cod5 diets supported $38.1 \%$ more body weight gain than the WT diets $(\mathrm{P}=0.06)$ (Figure 2$)$.

The Bone Mineral Density (BMD) is an important indicator for bone health [30]. The VDR-KO mice have lower BMD than C57BL/5 WT mice due to impaired Ca uptake and metabolism [32,33]. BMD was measured at day 1 and day 20 of the dietary regime and the increase of BMD was calculated for mice given each of the five diets (Table 1) groups $(n=10)$. The percentage increase of BMD at day 20 compared
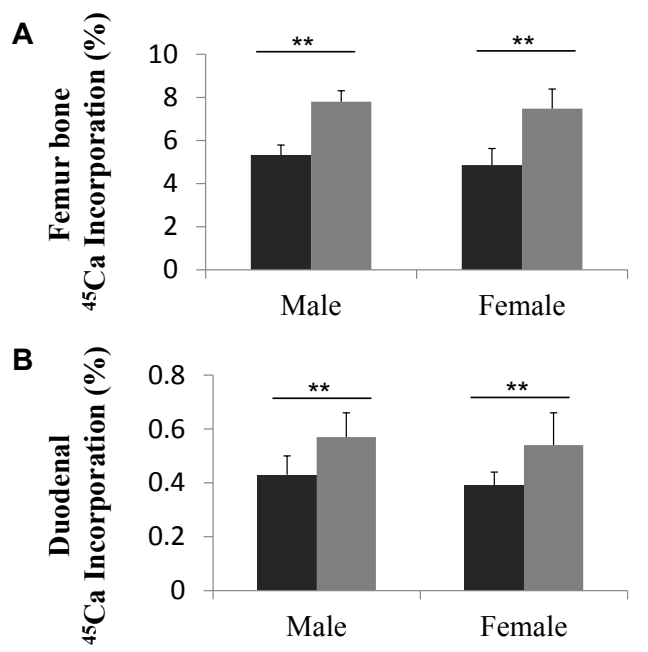

Figure 1: Hind limb bone and duodenal ${ }^{45} \mathrm{Ca}$ incorporation in VDR-KO mice fed wild-type ( $\square$ ) or cod5 ( $\square$ ) Medicago diet.

A, Incorporation rate of ${ }^{45} \mathrm{Ca}$ per $1 \mathrm{gram}$ of ash in the femur bones in both male and female VDR-KO mice. $\mathrm{B}$, DuodenalC $\mathrm{a}^{45}$ incorporation rate in both male and female VDR-KO mice. For both panel $A$ and $B: n=6$; The error bars represent standard deviation. **: $\mathrm{P}$ value for T-test between wild-type and cod5 group is less than 0.01 
Citation: Li X, Yang J, Morris J, Hester A, Nakata PA, et al. (2013) Genetically Modified Medicago truncatula Lacking Calcium Oxalate has Increased Calcium Bioavailability and Partially Rescues Vitamin D Receptor Knockout Mice Phenotypes. J Bioequiv Availab 5: 047-052. doi:10.4172/ jbb.1000133

to day 1 was calculated for each mice. The $0.5 \%$ Ca diet group showed an average of $13.65 \pm 1.78 \% \mathrm{BMD}$ increase while the $2 \%$ Ca diet group showed an average of $27.82 \pm 1.55 \% \mathrm{BMD}$ increase. The $\mathrm{CaOx}$ diet group had an average of $16.03 \pm 1.81 \%$ BMD increase. The cod5 diet group showed an average of $20.50 \pm 2.98 \%$ increase while the WT diet group showed an average of $17.56 \pm 2.21 \%$ increase in BMD. The cod5 diet supported $16.7 \%$ higher BMD increase in VDR-KO mice than WT Medicago diet $(\mathrm{P}=0.17)$ (Figure 3).

\section{Discussion}

While multiple avenues are available to achieve adequate dietary $\mathrm{Ca}$ intake, adequate $\mathrm{Ca}$ nutrition remains an unresolved nutritional issue [8]. Since the bioavailability of $\mathrm{Ca}$ varies greatly among various types of foods, information merely listing the amounts of $\mathrm{Ca}$ in foods is misleading [34]. Calcium absorption from plants appears to be inversely proportional to the crystalline oxalic acid content in food $[2,14,15,35]$. The ability to rapidly identify and characterize gene function and then utilize these genes to engineer plant metabolism has been a driving force in biofortification efforts [36]. The cod5 mutation in Medicago

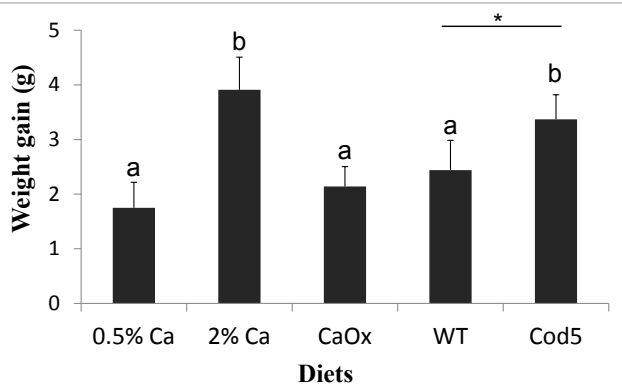

Figure 2: Weight gain of VDR-KO mice fed with five isocaloric diets containing different calcium sources over 20 days.

$0.5 \% \mathrm{Ca}$ : diet in which the Ca source is the AIN-93G diet base; $2 \% \mathrm{Ca}$ : diet in which additional $\mathrm{CaCl}_{2}$ was added to AIN-93G to achieve final Ca concentration of $2 \%$; $\mathrm{CaO}$ : diet in which additional $\mathrm{CaC}_{2} \mathrm{O}_{4}$ was added to AIN-93G to achieve final $\mathrm{Ca}$ concentration of $2 \%$; WT and cod5: diets in which either processed WT or cod5 Medicago was added to AIN-93G to achieve final Ca concentration of $2 \% . n=10$ for $0.5 \%, 2 \% \mathrm{Ca}$ and $\mathrm{CaOx}$ group; $\mathrm{n}=20$ for WT and cod5 group. The error bars represent standard error. $a$ and $b$ represent statistically significantly different groups. $\mathrm{P}$ value for $\mathrm{T}$-test between $\mathrm{a}$ and $\mathrm{b}$ group is less than 0.02 except for WT vs. cod5 group ( ${ }^{*}: \mathrm{P}=0.06$ ).

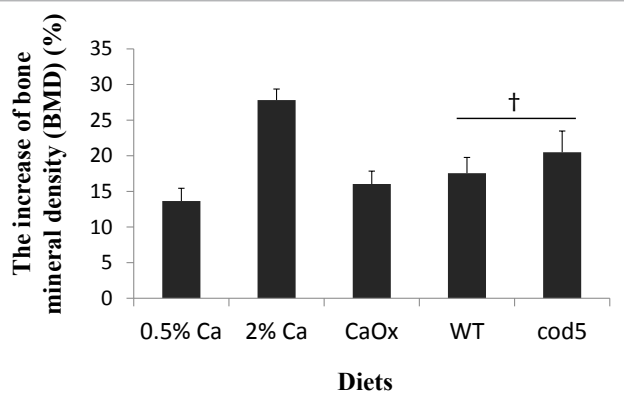

Figure 3: The percentage increase of bone mineral density (BMD) in VDR-KO mice fed five isocaloric diets containing different calcium sources over 20 days.

$0.5 \% \mathrm{Ca}$ : diet in which the Ca source is the AIN-93G diet base; $2 \% \mathrm{Ca}$ : diet in which additional $\mathrm{CaCl}_{2}$ was added to $\mathrm{AIN}-93 \mathrm{G}$ to achieve final $\mathrm{Ca}$ concentration of $2 \%$; $\mathrm{CaOx}$ : diet in which additional $\mathrm{CaC}_{2} \mathrm{O}_{4}$ was added to AIN-93G to achieve final $\mathrm{Ca}$ concentration of $2 \%$; WT and cod5: diets in which either processed WT or cod5 Medicago was added to AIN-93G to achieve final Ca concentration of $2 \% . n=10$ for all diet groups. The error bars represent standard error. $\dagger: P$ $=0.17$. causes removal of crystalline $\mathrm{CaOx}$ complexes but unchanged total $\mathrm{Ca}$ levels and presents an attractive target for efforts to increase $\mathrm{Ca}$ bioavailability.

In our previous work [6], we fed equal number of male and female mice four ${ }^{45} \mathrm{Ca}$-containing diets: WT $M$. truncatula extrinsically or intrinsically labeled with ${ }^{45} \mathrm{Ca}$, and cod5 extrinsically or intrinsically labeled with ${ }^{45} \mathrm{Ca}$. Extrinsic labeling adds the tracer to the food before ingestion, whereas for intrinsic labeling plants are grown in the presence of the label to incorporate the tracer into the plant matrix. Using both diets, absorption of the tracer was determined one day after consumption. Only in the intrinsically labeled diets, did we note a difference among the diets? We postulate these findings during the formation of crystals in Medicago, much like oxalate crystals in spinach, $\mathrm{Ca}$ is bound in a non-bioavailable form. In this study we used only intrinsically labeled foods.

The primarily limitations of using C57BL/6 WT mice is that there is no phenotypes to "rescue" with the modified diets. The level of $\mathrm{Ca}$ in cod5 diets, though low, is sufficient to support C57BL/6 mice growth and development so that no obvious phenotypes can be detected. VDR-KO mice have lost the ability to absorb Vitamin D3 -dependent $\mathrm{Ca}$ [37]. The VDR-KO mice serum/bone Ca levels are $40 \%$ lower than WT mice when fed with $0.5 \% \mathrm{Ca}$ diets (equivalent to $\mathrm{Ca}$ in AIN-76A diets) [37]. Due to this decreased Ca absorption, VDR-KO mice have impaired body growth and bone formation [21]. However, VDR-KO mice have the same serum/bone Ca levels as the WT when fed high Ca diets [37]. Continuous feeding with Ca enriched diets partially rescues the bodyweight and bone formation phenotypes [21]. Utilizing VDR$\mathrm{KO}$ mice, here we simultaneously tested Ca bioavailability in cod5 in the hind limbs and duodenum. The phenotypes associated with VDR$\mathrm{KO}$ mice disruption are most pronounced in the intestine as this is a key tissue that regulates $\mathrm{Ca}$ uptake $[30,32]$. Our results indicate that the higher levels of bioavailable $\mathrm{Ca}$ in cod5 plants lead to increased $\mathrm{Ca}$ absorption in duodenum and incorporation in hind limbs in VDRKO mice. Moreover, in the 20-day feeding study, our results showed that $\operatorname{cod} 5$ was able to provide more bioavailable Ca to VDR-KO mice than WT Medicago and support bone mass and body weight gain in a similar manner to diets supplemented with exogenous Ca. Overall, our results further support the hypothesis that single gene alterations in $\mathrm{CaOx}$ formation in plants can boost Ca bioavailability.

Previous work with C57BL/6 mice has noted sex differences in bone formation. This may indicate a sex-based difference in preserving structural properties of the skeleton [38]. In our feeding study, we also detected male VDR-KO mice were more sensitive to Ca uptake and this might be a result of the male mice's need for more Ca to support its higher bodyweight than females (Data not shown). However, both male and female VDR-KO mice fed cod5 demonstrated better Ca uptake and bone health and the benefits of the cod5 diets in VDR-KO mice is not gender specific (Figure 1). Our test groups were relatively small and we noted substantial individual variability in feeding behaviors that likely resulted in $\mathrm{P}$ value being higher than 0.05 . The $\mathrm{P}$ value for the long term bodyweight and BMD tests were $\mathrm{P}=0.06$ and $\mathrm{P}=0.17$ respectively. These values would have been smaller than 0.01 . However, one VDRKO mouse fed the cod5 diet did not consume the food during the test period and the animal's bodyweight and BMD didn't increase (data not shown). Thus, while are results are not statistically significant, the trend is apparent. Large quantities of plant material for the longterm feedings were required and plant rearing space was an issue. In order to provide the diets for 20 days we compromised on the number 
Citation: Li X, Yang J, Morris J, Hester A, Nakata PA, et al. (2013) Genetically Modified Medicago truncatula Lacking Calcium Oxalate has Increased Calcium Bioavailability and Partially Rescues Vitamin D Receptor Knockout Mice Phenotypes. J Bioequiv Availab 5: 047-052. doi:10.4172/ jbb.1000133

of animals analyzed. Nonetheless, our data demonstrate a difference between cod5 and WT Medicago lines (Figure 2).

Disruption of one allele of the VDR-KO gene has been shown to impact bone development and impart metabolic consequences [39]. VDR heterozgyous mutant (VDR HET) male mice have normal skeletal development until 16 weeks of age but show significantly less gain in fat mass than WT mice. In contrast, female VDR HET mice show decreased total-body BMD at 8 weeks. In the future, studies using cod5 diets in the VDR HET mice may be informative.

Using foods to attenuate genetic disorders is not a novel concept. Several genetic diseases have been linked to altered mineral nutrition and can be attenuated by dietary therapies. For example, Mitral valve prolapse syndrome (MVP) is a frequent disorder characterized by a number of complaints that lessen the quality of life. Many patients with MVP have low serum magnesium, and supplementation of this ion leads to improvement in most symptoms [40]. However, using modified foods to suppress genetic disorders is an exciting prospect that will require further testing.

If $\mathrm{Ca}$ levels are low, $\mathrm{Ca}$ supplements may be prescribed to ameliorate phenotypes. Sometimes, Ca based phosphorus binders are prescribed to treat both low $\mathrm{Ca}$ and high phosphorus levels. Our work here suggests that foods high in $\mathrm{Ca}$ but low in $\mathrm{CaOx}$ may also be used as a dietary regime to help patients with chronically low Ca levels.

The low Ca bioavailability in common plant food sources makes it difficult for most vegetarians to meet their $\mathrm{Ca}$ intake demands. The work performed with Medicago can serve as a guide for biofortification effort in food plants. Based on our findings, we can predict the benefits in removing oxalate in other common vegetables such as spinach. Currently, work is undergoing to determine the genetic lesion in the cod5 lines. Once the COD5 gene is cloned and characterized, work can be undertaken to modify the COD5 homologs in spinach and other vegetables [17].

\section{Conclusions}

Our results further confirm that cod5 Medicago has increased Ca bioavailability compared to WT Medicago. In a long term feeding regime, removal of oxalate from the plant matrix increased absorbed $\mathrm{Ca}$ and deposited bone $\mathrm{Ca}$ in the consuming animal, thus conveying the idea that genetic changes in food crops can help attenuate effects in genetically susceptible individuals. Our study supports the concept of decreasing antinutrients in crops as an exciting strategy for long-term biofortification strategies to improve nutrient intake.

\section{Acknowledgements}

We thank Tracy Punshon for editing portions of the manuscript. Funding for this work came from the Fundamental Research Funds for the Central Universities Izujbky-2011-32 to X. Li and the U.S. Department of Agriculture/Agricultural Research Service (under cooperative agreement 58-62650-6001), and the U.S. Department of Agriculture Grant CSRESS\#2005-34402-16401 Designing Foods for Health to KDH and to PAN by the U.S. Department of Agriculture/Agricultura Research Service (under cooperative agreement 58-6250-0-008)

\section{References}

1. Craig WJ (2009) Health effects of vegan diets. The American Journal of Clinical Nutrition 89: 1627S-1633S.

2. Weaver CM (1990) Assessing calcium status and metabolism. J Nutr 11: 14701473.

3. Nilas L (1993) Calcium intake and osteoporosis. World Rev Nutr Diet 73: 1-26.

4. IOM (1997) Dietary reference intakes for calcium, phosphorus, magnesium,
Vitamin D, and fluoride. A report of the panel on calcium and related nutrients and the standing committee on the Scientific Evaluation of Dietary References Intakes., F.a.N. Board, Editor 1997, Institute of Medicine.

5. (1994) Optimal calcium intake NIH Consensus statement 12: 1-31.

6. Morris J, Nakata PA, McConn M, Brock A, Hirschi KD (2007) Increased calcium bioavailability in mice fed genetically engineered plants lacking calcium oxalate. Plant Mol Biol 64: 613-618.

7. Morris J, Keli MH, Tim H, Steven AA, Kendal DH (2007) Nutritional impact of elevated calcium transport activity in carrots. Proc Natl Acad Sci 105: 1431 1435.

8. Johnson-Down L, L'Abb MR, Lee NS, Gray-Donald K (2003) Appropriate calcium fortification of the food supply presents a challenge. J Nutr 133: 2232 2238.

9. Linder MC (1991) Nutritional Biochemistry and Metabolism: With Clinical Applications. 2nd edn New York: Elsevier Publishers.

10. 10.http://www.healthguidance.org/entry/6265/1/Bioavailability-How-the Nutrients-in-Food-Become-Available-to-Our-Bodies.html

11. Kamchan A, Puwastien $P$, Sirichakwal $P$, Kongkachuichai $R$ (2004) In vitro calcium bioavailability of vegetables, legumes and seeds. J Food Compost Anal 17: 311-320.

12. Heaney RP, Weaver CM, Recker RR (1988) Calcium absorbability from spinach. Am J Clin Nutr 47: 707-709.

13. Massey LK, Palmer RG, Horner HT (2001) Oxalate content of soybean seeds (Glycine max: Leguminosae), soyfoods, and other edible legumes. J Agric Food Chem 49: 4262-4266.

14. Prenen JA, Boer P, Dorhout Mees EJ (1984) Absorption kinetics of oxalate from oxalate-rich food in man. Am J Clin Nutr 40: 1007-1010.

15. Weaver CM, Martin BR, Ebner JS, Krueger CA (1987) Oxalic acid decreases calcium absorption in rats. J Nutr 117: 1903-1906.

16. Bohn T, Davidsson L, Walczyk T, Hurrell RF (2004) Fractional magnesium absorption is significantly lower in human subjects from a meal served with an oxalate-rich vegetable, spinach, as compared with a meal served with kale, a vegetable with a low oxalate content. Br J Nutr 91: 601-606

17. Nakata PA (2012) Plant calcium oxalate crystal formation, function, and its impact on human health. Front Biol 7: 254-266.

18. Nakata PA, McConn MM (2000) Isolation of Medicago truncatula mutants defective in calcium oxalate crystal formation. Plant Physiol 124: 1097-1104.

19. Nakata PA, McConn MM (2003) Calcium oxalate crystal formation is not essential for growth of Medicago truncatula. Plant Physiol Biochem 41: 325 329.

20. Ceglia L (2008) Vitamin D and skeletal muscle tissue and function. Mol Aspects Med 29: 407-414.

21. Yoshizawa T, Handa Y, Uematsu Y, Takeda S, Sekine K, et al. (1997) Mice lacking the vitamin $\mathrm{D}$ receptor exhibit impaired bone formation, uterine hypoplasia and growth retardation after weaning. Nat Genet 16: 391-396.

22. Kato S, Takeyama K, Kitanaka S, Murayama A, Sekine K, et al. (1999) In vivo function of VDR in gene expression-VDR knock-out mice. J Steroid Biochem Mol Biol 69: 247-251.

23. Li YC, Bolt MJ, Cao LP, Sitrin MD (2001) Effects of vitamin D receptor inactivation on the expression of calbindins and calcium metabolism. Am J Physiol Endocrinol Metab 281: E558-564.

24. Yagishita N, Yamamoto Y, Yoshizawa T, Sekine K, Uematsu Y, et al. (2001) Aberrant growth plate development in VDR/RXR gamma double null mutant mice. Endocrinology 142: 5332-5341.

25. Song Y, Kato S, Fleet JC (2003) Vitamin D receptor (VDR) knockout mice reveal VDR-independent regulation of intestinal calcium absorption and $\mathrm{ECaC2}$ and calbindin D9k mRNA. J Nutr 133: 374-380.

26. Masuyama R, Nakaya Y, Tanaka S, Tsurukami H, Nakamura T, et al. (2001) Dietary phosphorus restriction reverses the impaired bone mineralization in vitamin D receptor knockout mice. Endocrinology 142: 494-497.

27. Nakata PA, McConn MM (2006) A genetic mutation that reduces calcium oxalate content increases calcium availability in Medicago trunculata. Plan Biol 303. 
Citation: Li X, Yang J, Morris J, Hester A, Nakata PA, et al. (2013) Genetically Modified Medicago truncatula Lacking Calcium Oxalate has Increased Calcium Bioavailability and Partially Rescues Vitamin D Receptor Knockout Mice Phenotypes. J Bioequiv Availab 5: 047-052. doi:10.4172/ jbb.1000133

28. McConn MM, Nakata PA (2002) Calcium oxalate crystal morphology mutants from Medicago truncatula. Planta 215: 380-386.

29. Li X, Yang J, Manary M, Hirschi KD (2012) Biotechnologically-Modified Cassava: Protein Absorption Relative to Casein. J Bioequiv Availab 4: 040-043.

30. Holmen SL, Giambernardi TA, Zylstra CR, Buckner-Berghuis BD, Resau JH, et al. (2004) Decreased BMD and limb deformities in mice carrying mutations in both Lrp5 and Lrp6. J Bone Miner Res 19: 2033-2040.

31. Abrams SA, Griffin IJ, Hawthorne KM, Chen Z, Gunn SK, et al. (2005) Vitamin $\mathrm{D}$ receptor Fok1 polymorphisms affect calcium absorption, kinetics, and bone mineralization rates during puberty. J Bone Miner Res 20: 945-953.

32. Wynne F, Drummond F, O'Sullivan K, Daly M, Shanahan F, et al. (2002) Investigation of the genetic influence of the OPG, VDR (Fok1), and COLIA1 Sp1 polymorphisms on BMD in the Irish population. Calcif Tissue Int 71: 26-35.

33. Yu B, Wu H, Li F, Gong J, Zhou D, et al. (2011) Change of BMD after weaning or resumption of menstruation in Chinese women with different FokI VDRgenotypes: a randomized, placebo-controlled, calcium supplementation trial. Biomed Environ Sci 24: 243-248.

34. Titchenal CA, Dobbs J (2007) A system to assess the quality of food sources of calcium. J Food Compost Anal 20: 717-724.

35. Heaney RP, Recker RR (1988) Estimating true fractional calcium absorption Ann Intern Med 108: 905-906.

36. Christou P, Twyman RM (2004) The potential of genetically enhanced plants to address food insecurity. Nutr Res Rev 17: 23-42.

37. Haussler MR, Whitfield GK, Haussler CA, Hsieh JC, Thompson PD, et al (1998) The nuclear vitamin $D$ receptor: biological and molecular regulatory properties revealed. J Bone Miner Res 13: 325-349.

38. Harper BL, Ramanujam VM, Legator MS (1989) Micronucleus formation by benzene, cyclophosphamide, benzo(a)pyrene, and benzidine in male, female pregnant female, and fetal mice. Teratog Carcinog Mutagen 9: 239-252.

39. de Paula FJ, Dick-de-Paula I, Bornstein S, Rostama B, Le P, et al. (2011) VDR haploinsufficiency impacts body composition and skeletal acquisition in a gender-specific manner. Calcif Tissue Int 89: 179-191.

40. Lichodziejewska B, Klos J, Rezler J, Grudzka K, Dluzniewska M, et al. (1997) Clinical symptoms of mitral valve prolapse are related to hypomagnesemia and attenuated by magnesium supplementation. Am J Cardiol 79: 768-772. 